\title{
High quality pasture feed for southern New Zealand - a consequence of cul- tivar choice and their subsequent management
}

\author{
J.D. TURNER \\ AgResearch, Private Bag, Gore
}

\begin{abstract}
High quality pasture feed is a direct consequence of species/cultivar choice and subsequent management. The pasture mixture must be selected according to the environment in which they are to grow, end use and speed of establishment. Important establishment factors are seedingrate, seedbed preparation, sowing time and soil nutrient status. Once established, correct grazing management and maintenance will ensure longevity of pasture life and continued availability of high quality animal feed.
\end{abstract}

Keywords cultivars, establishment, grazing, growth environment, pasture quality, seedbed, seed rate, soil nutrients, sowing time

\section{Introduction}

Southern New Zealand is renowned for its high quality and high output of animal product, mainly because of a cool and reliably moist (although some inland parts are seasonally dry) climate that allows adequate feed availability throughout the year.

To sustain or improve the high animal production from our pastoral farming systems the available feed must be of the highest quality possible.

Three main factors determine the availability of high quality animal feed from our pastures:

- plant species

- cultivar choice

- establishment and management

\section{Establishment}

Establishment is the first stage in pasture management and perhaps the most critical. What you do at this stage of your high quality pasture's life can make or break it. Important establishment factors are:

\section{- Species/cultivar m i x}

- Seeding rates

- Seedbed preparation/sowing time

- Soil nutrient status - Initial grazing management

\section{Species and cultivars}

Grass species includes perennial ryegrass, Italian ryegrass, cocksfoot. tall fescue; legume species includes white clover, red clover, luceme. Other plant species include herbs such as chicory. Each species has a range of characteristics. many of which are particular to that species.

Individual plant species are usually represented by more than one cultivar. particularly when the worldwide scene is taken into account. Perennial ryegrass, for example, is represented by more than 12 cultivars commercially available in New Zealand and in excess of 100 worldwide. Each cultivar may have particular characteristics that make it useful in either a wide range of environments or a quite specific environment. In recognition of commercial sensitivity, this paper will mainly address the role of species rather than cultivars in pastoral systems.

\section{Seed selection}

In choosing your species/cultivar mix consideration must be given to the environment in which they are to grow, the end use and relative speed of establishment.

Most of southern New Zealand has a reliable moist environment and cultivars from withinthe ryegrass (low endophyte) and white clover species will provide high quality animal feed difficult to surpass. The ability to use low endophyte ryegrass for permanent pastures is unique to southern New Zealand where the cooler environment prevents build up of the insect pest Argentine stem weevil to damaging levels (JPJ Eercns pers. comm).

However, some localised environments have regular soil moisture deficits and the use of deeper rooting species such as tall fescue. cocksfoot and phalaris or taprooted species like red clover. luceme and chicory is preferable to shallow rooting species such as ryegrass and white clover. Similarly, if the environment is insect prone then species and cultivars known to have tolerance or resistance should be used. These include the deeper rooting species mentioned above.

When considering end use, the ultimate grazing management of the plants is most important. For example, virtually all species/cultivars will perform to their potential when rotationally grazed, whereas relatively few, perennial ryegrasses and some white clovers, 
for example, tolerate extended periods of continuous grazing. End use also encompasses the special purpose, high quality pastures that are used for animal finishing, milk production and hay or silage conservation. In this instance plants chosen might have high protein (legumes), high digestibility (Italian ryegrass) or special nutritional qualities (chicory).

Succesful establishment of the individual components of a mix also depends on their relative rate of establishment. Combiig slow establishing species such as tall fescue with fast establishers like ryegrass is not desirable. The slower less aggressive types will suffer from competition and early grazing pressures (Lancashire \& Brock 1983; Charlton 1992).

The importance of finding out all the information possible about species/cultivars and their sowing rates before making your mixture selection cannot be overemphasised. Read the fine print and ask questions.

\section{Seed sowing rates}

Having chosen the species/cultivars to make up your mix you must then consider how much seed of each to sow. A useful guide for the amount of seed to sow of most grasses is the equivalent of $1000 \mathrm{seeds} / \mathrm{ma}$ (Table 1).However, for cultivars having very large seeds, such as bromes or tetraploid ryegrasses, as few as 250 and 750 seeds $/ \mathrm{m}^{2}$. respectively. are sufficient. For legumes, a sowing rate of $500 \mathrm{seeds} / \mathrm{m}^{2}$ is sufficient for most, although for large seed cultivars, such as red clovers, fewer are satisfactory.

For binary pasture mixtures the individual species sowing rates are shown in Table 1 . There is little need to vary these rates because in practice only a relatively small number of the seeds sown (less than 50\%) establish as plants (Charhon 1992). If seed viability is lower than $85 \%$ ex-store then sowing rates should be increased upwards accordingly.

When multi-cultivar mixtures of grasses and legumes are to be sown, consideration must initially be given to the desired dominance of each individual cultivar in the mix. Then, seed ratios can be worked out within the previously mentioned guidelines. As an example of a multi-aultivar mix consider the situation of a light soil that suffers occasional moisture stress, grass grub infestation. and is to be set stocked through spring. A mix of perennial ryegrass, cocksfoot and white dover is decided on, with the grass to be predominantly ryegrass (75\%). The per hectare sowing rates would be perennial ryegrass $14 \mathrm{~kg}$, cocksfoot $2 \mathrm{~kg}$ and white dover $3 \mathrm{~kg}$.

The addition of a species such as the herb chicory to a pasture mixture adds a further dimension to working out seeding rates. Thii species has the potential to grow to quite large individual plant size, and to realise this potential the plants must have sufficient space. One example is perennial ryegrass $6 \mathrm{~kg} / \mathrm{ha}$, chicory $3 \mathrm{~kg}$ and white clover $3 \mathrm{~kg}$. The ryegrass rate is kept low and therefore each component is given the opportunity to express itself fully.

Table 1 Weight and number characteristics and suggested sowing rates for some common pasture species (after Charlton 1992).

\begin{tabular}{|c|c|c|c|c|c|}
\hline Species 1000 seed & $\begin{array}{c}\text { Seeds/kg } \\
W t(g)\end{array}$ & Seeds/m $m^{2}$ & $\begin{array}{l}\text { Sowing rete } \\
\text { II } \mathrm{kg} / \mathrm{ha}\end{array}$ & $\begin{array}{l}\text { Sowing rate } \\
\text { in binary mix }\end{array}$ & $\begin{array}{l}\text { Sowing rate } \\
\text { in multi-mix }\end{array}$ \\
\hline \multicolumn{6}{|l|}{ Legumes } \\
\hline $\begin{array}{l}\text { White Clover } \\
\text { Red Clover: }\end{array}$ & 0.6 & $1,670,000$ & 170 & 3 & $2-3$ \\
\hline tetraploid & 3.4 & 295.000 & 30 & 7 & $3-6$ \\
\hline diploid & 1.9 & 525,006 & 50 & 4 & $2-4$ \\
\hline Lucerne & 2.0 & 500.000 & 50 & 10 & $6-10$ \\
\hline \multicolumn{6}{|l|}{ Grasses } \\
\hline $\begin{array}{l}\text { Perennial ryograss } \\
\text { Italian ryegrass: }\end{array}$ & 1.8 & 555.000 & 55 & 18 & $6-15$ \\
\hline tetraploid & 4.0 & 250.000 & 25 & 30 & 10.20 \\
\hline diploid & 2.0 & 500,000 & 50 & 20 & $10-15$ \\
\hline \multicolumn{6}{|l|}{ Hybrid ryegrass: } \\
\hline tetraploid & 4.0 & 250,006 & 25 & 25 & 10.20 \\
\hline diploid & 1.8 & 555,006 & 55 & 18 & $5-15$ \\
\hline Cockstoot & 0.8 & $1,250,000$ & 125 & 8 & $2-6$ \\
\hline Tall fescue & 2.6 & 365,000 & 40 & 25 & 10.20 \\
\hline Timothy & 0.4 & 2500.000 & 250 & 4 & I-2 \\
\hline Phalaris & 2.0 & 500,000 & 50 & & I-2 \\
\hline Grazing brome & 11.5 & 67.000 & 9 & 30 & $10-20$ \\
\hline \multicolumn{6}{|l|}{ Herb } \\
\hline Chicory & 1.2 & 830,000 & 65 & 4 & $\mathrm{I}-3$ \\
\hline
\end{tabular}




\section{Seedbedandsowing}

Having decided on the seed mix and sowing rates the next important establishment criteria to be considered are seedbed preparation and soil nutrient status.

There are three main seedbed preparation/sowing techniques:

- Full cultivation

- Spray/direct drill

- Hoof and tooth oversowing

It is generally recognised that full cultivation to produce a fine tilth and fii seed bed, with seed buried at least $10 \mathrm{~mm}$ and to no more than $20 \mathrm{~mm}$, is the ideal pasture sowing technique. However, where land contour is relatively uniform the spray/direct drill technique will also give good results and has the added benefit that pastures are out of production for a shorter time.

The hoof and tooth technique is, generally ,usedonly in inaccessible and untillable areas such as hill country. Here, existing pasture is hard grazed and seed introduced with animals left on for 2-3 days to trample seed into close contact with soil.

\section{Time of sowing}

Tie of sowing is yet another important factor in establishing high quality pastures.

Miniium soil temperatures of $10^{\circ} \mathrm{C}$ or greater are essential. Temperatures above $15^{\circ} \mathrm{C}$ for slow establishing species such as tall fescue give an advantage. Reliable soil moisture availability for 3-6 months after sowing is also a requirement for successful establishment.

To put these factors into context it is possible to establish pastures in the reliably moist areas of southern New Zealand from mid spring to early autumn. For the opposite extreme - areas with regular summer moisture deficits - early- to mid-autumn sowings are most reliable.

\section{Soil nutrients}

Before sowing any high quality pasture mix, full regard must also be given to the soil nutrient status.

High performance cultivars will realise their potential only if all necessary elements are adequately available. This includes both the macro-nutrients such as nitrogen, phosphorous, potassium and sulphur and the micro-nutrients such as molybdenum. Available and desirable levels of plant nutrients vary according to soil type and climate and it is most important to use chemical analysis of soils to establish appropriate levels of nutrient provision.

Soil acidity should also be at a desirable level. Most plants prefer a slightly acid situation - $\mathrm{pH} 5.7$ to 6.3 .

\section{Grazing management}

Having fertilised and sown the chosen high quality pasture mix the last of the important factors for successful establishment and pasture longevity - grazing management - must be considered.

\section{Establishment management}

For fast establishing species, such as ryegrass. the initial grazing after sowing can be as soon as 6 weeks in warm conditions. Slow establishing species, tall fescue and cocksfoot for ex ample, may require as long as 12 weeks, particularly if cooler conditions prevail. Within this time frame, pasture height, at the time of initial grazing, should be in the range $150-200 \mathrm{~mm}$.

The initial grazing should be as quick as possible: around 48 hours is preferable and any longer than 3 days is undesirable. The intensity of the first grazing is also important. A residual pasture height of no less than 50 $\mathrm{mm}$ will promote fast regrowth and plant development.

Subsequent grazings during establishment, up to 12 months for most species. should also be within the above-mentioned height limits, but grazing duration can be extended to 5-7 days.

\section{Long-term management}

Having put so much care and attention into setting up your high quality pasture it makes sense that the same effort should also be put into its long-term management. This means regular soil testing and maintenance fertiliser, insect protection where appropriate, and using the correct grazing management for the species sown (i.e. do not set stock plants intolerant of it).

Two further management tools are also available to assist in providing high quality animal feed from your pastures. Topping can be used to remove mature, and therefore less digestible, herbage, such as seedhead. Hay orsilage conservation will remove surplus production at peak growth periods, thereby assisting the maintenance of normal grazing rotation frequency.

\section{Summary}

Providing high quality pasture feed will greatly assist in maximising animal performance. For example additional lamb growth rates of up to $150 \mathrm{~g} / \mathrm{head} / \mathrm{day}$ (D.R. Stevens and J.D. Turner, unpub. data; J.P.J. Eerens pers. 
comm.) and dairy cow milk production of $3 \mathrm{I} / \mathrm{cow} /$ day (Tumer unpub. data) have resulted from the use of high quality pastures.

Economic analysis has shown that, even allowing for gains lower than those quoted. the $\$ 220$ to $\$ 700$ cost of establishing high quality pastures is profitable (G. Milne pers. comm).

Excellent pasture feed will be more reliably guaranteed by choosing, as a result of available information, the most suitable cultivars for a particular environment and establishing and managing them correctly.

\section{REFERENCES}

Charlton. J. F. L. 1992. Some basic concepts of pasture seed mixtures for New Zealand farms. Proceedings of the New Zealand Grassland Association 53: 3740.

Lancashire, J A; Brock, J L 1983. Management of new cultivars for dryland. Proceedings of the New Zealand Grassland Association 44: 61-73 